\title{
THE HOBBESIAN TRAP AND THE HAREM
}

\author{
Fatma Dore \\ Afyon Kocatepe University, Turkey
}

\begin{abstract}
This paper will demonstrate that for Thomas Hobbes, man has the right of self-preservation and the obligation to act in accordance with that right. The problem of this obligation is that there can be no objective method for an individual to determine an existential threat, but only a subjective one. It is the subjective judgment of the individual that leads to the problem of pre-emptive violence or the Hobbesian Trap. As the individual is left to determine a threat to his life, he has the obligation to neutralize that threat regardless of the intention of this supposed treat and regardless of whether he wishes to act violently. This paper will also examine how, by expanding the concept of the "self" that is obliged to be defended in accordance with an observation of Hobbes, the Hobbesian Trap can additionally encompass perceived threats to one's self-regard or honor. This paper will reveal that within the frame story of The Thousand and One Nights, such a broad-based Hobbesian Trap is in operation in the action of Shahriyar in his execution of his newly-wedded wives on the morning after consummating his marriages to them. It will demonstrate that he acts pre-emotively to protect what he regards as potential threats to his honor. It will finally show that one method for defusing the Hobbesian Trap is through trust-building, and that Shahrazad wins the confidence of Shahriyar thus causing him to spare her life and abandon pre-emptive bride killing.
\end{abstract}

Keywords: Thomas Hobbes; The Thousand and One Nights; Preemptive Attack; Shahriyar; Shahrazad.

\section{Introduction}

Revealing the causes of violence amongst man for the seventeenthcentury English political philosopher Thomas Hobbes in the state of nature, Iain Hampsher-Monk (1992: 24) states that:

It is instructive to notice...the causes of this violence. It derives from the very qualities which are commonly thought of as being the basis of human political sociability, our supposed equality and rationality. 
Although Hobbes uses the device of a state of nature, the conflict in it does not arise because men there are intellectually primitive or beastlike; quite the opposite: it arises from their equality, and a presumption of their equal skill and sophistication at reasoning. Not the least of Hobbes' paradoxes is that the worst features of human life derive, not from their lapses into beastliness, but from their very humanity.

The idea of equality and rationality being a cause rather than an inhibitor of violence is, at first thought, a shockingly unexpected one. Violence is often regarded as an act of domination compelled by irrational drives. For instance, writing on the subject of what he calls "irrational violence in America", Franklin A. Zimring (1998) avers that "[t]hose who believe that human behavior is governed by rational principles are hard put to explain much of America's violent crime." Nevertheless, violence becomes far more disturbing when it not only cannot be explained away by a deficient use of the mental faculties of its initiators, but is actually results from their rationality. It becomes more disturbing still if it is thought that rationality can lead these initiators into violence against otherwise peaceful inclinations. Yet, this is precisely what the concept known as "The Hobbesian Trap", which as its name suggests is solidly based upon the philosophy of Hobbes, affirms the possibility of.

This paper will demonstrate that for Thomas Hobbes, man has the right of self-preservation and the Reason-based obligation to act in accordance with that right (Hobbes, 1985: 189). The problem of this obligation is that there can be no objective method for an individual to determine an existential threat, but only a subjective one. This subjective method is not irrational however; quite the contrary, it entails reasoning upon necessarily limited information. This subjective judgement of the individual leads to the problem of pre-emptive violence or the Hobbesian Trap. As the individual is left to determine a threat to his life, once he has done so, he has the obligation to neutralize that threat regardless of the intention of this supposed threat and regardless of whether he wishes to act violently. This paper will also examine how, by expanding the concept of the "self" that is obliged to be defended in accordance with an observation of Hobbes, the Hobbesian Trap can additionally encompass perceived threats to one's self-regard or honour. This paper will then show an example of this wider-based Hobbesian Trap exists within one of the great works of world literature. It will reveal that within the frame story of The Thousand and One Nights, such a broad-based Hobbesian Trap is in operation in the action of Shahriyar in his execution of his 
newly-wedded wives on the morning after consummating his marriages to them. It will demonstrate that he acts with subjective rationally to pre-emptively protect what he regards as potential threats to his honour. It will finally show that one method for defusing the Hobbesian Trap is through trust-building. This too is evidenced in the frame story of The Thousand and One Nights ${ }^{1 *}$ (Dawood, 1973: 405) with Shahrazad winning the confidence of Shahriyar thus causing him to spare her life and abandon pre-emptive bride killing, which is "salvation" for him.

\section{The Hobbesian Trap}

The Hobbesian trap reveals how violence can logically ensue from a situation in which the actors are only interested in self-defence. Superficially of course, if the actors in a situation are only interested in defending themselves, it would appear than violence were impossible, as self-defence can only occur when an actor is actually attacked. In order to reveal how the Hobbesian Trap expands the potential to violence, the concept and context of self-preservation for Hobbes needs to be examined first.

Hobbes, as befitted a post-Montaigne thinker, had a sceptical and relativistic view of ethics. Unlike Locke, he did not believe in the existence of a natural moral law. Instead, save for one caveat, he, in the words of Tuck (1992: 172) regarded "any belief" as being "possible." Yet, his caveat is that he did recognize what he saw as a universal value and this he regarded as a natural right; the only natural right. It is that of selfpreservation. Hobbes (2008: 78-9) explains why this is the natural right:

$[F]$ orasmuch as necessity of nature maketh men to will and desire bonum sibi, which is good for themselves, and to avoid that which is hurtful; but most of all that terrible enemy of nature, death, from whom we expect both the loss of power, and also the greatest of bodily pains in the losing; it is not against reason that man doth all he can to preserve his own body and limbs, both from death and pain. And that which is not against reason, men call RIGHT, or jus, or blameless liberty of using our own natural power and ability. It is therefore a right of nature: that every man may preserve his own life and limbs, with all the power he hath.

By this, Hobbes (ibid) means that man he may rightfully "do whatsoever action is necessary for the preservation of his body." $\mathrm{He}$ states (1985: 189-90 - my italics) that "there is nothing he can make use

1) This work from hereon will be abbreviated as TON. 
of, that may not be a help unto him, in preserving his life against his enemyes" and that "[i]t followeth, that in such a condition, every man has a Right to everything; even to one another's body." Thus the right of self-preservation, yet only this right, can entail the termination of the threat to his own existence, and is the reason Hobbes (2008: 104) asserts that "nothing but fear can justify the taking away of another's life."

The problem of the right of self-preservation is that there can be no objective method of determining an existential threat, but only the subjective outlook of each individual. With "the condition of Man" in his natural form "is a condition...in which case everyone is governed by his own Reason", this subjective outlook is rational. It is merely necessarily limited in what it is able to reason upon (Hobbes, 1985: 189). For instance, Hobbes (1985: 192) makes the point that "a man cannot tell, when he seeth men proceed against him by violence, whether they intend his death or not." Moreover, in dealing with what an individual regards as an existential threat, he once again only has his own rational judgement to rely upon. Thus, Hobbes (1985: 189) affirms that:

The Right of Nature, which Writers commonly call Jus Naturale, is the Liberty each man hath, to use his own power, as he will himself, for the preservation of his own Nature; that is to say of his own Life; and consequently, of doing anything, which in his own Judgement, and Reason, hee shall conceive to be the aptest means thereunto.

Indeed, this right is in fact an obligation:

A Law of Nature (Lex Naturalis,) is a Precept, or generall Rule, found out by Reason, by which a man is forbidden to do, that, which is destructive of his life, or taketh away the means of preserving the same; and to omit, that, by which he thinketh it may be best preserved (Hobbes, 1985: 189 - my italics).

This obligation is reaffirmed by Hobbes' (1985: 192) assertion that "a man cannot lay down the right of resisting them, that assault him by force, to take away his life; because he cannot be understood to ayme thereby, at any Good to himself." Hobbes (1985: 190) reduces his argument to "the summe of the Right of Nature; which is, By all means we can, to defend our selves."

Hobbes, as has been seen, raises the question of an attack in which it is unclear whether the individual's death is intended or not. The individual himself is left to determine the nature of the threat. There 
is a wider implication though and that is that the individual is obliged to act in self-defence simply if he feels that his life is threatened. This is regardless of what is actually passing in the mind of the person he has identified as an attacker. Richard Tuck (1992: 173) provides the following theoretical example:

Suppose I see you walking peacefully through the primitive savannah, whistling and swinging your club: are you a danger to me? You may well think not: you have an entirely pacific disposition. But I may think you are, and the exercise of my natural right of self-preservation depends only on $m y$ assessment of the situation. So if I attack you, I must be justified in doing so.

This enables him to subjectively indentify as a threat someone that objectively is not. This is because within the question of the obligation of self-preservation, there is the problem that there can be no objective method of determining an existential threat, but only the subjective outlook of each individual. And, Hobbes demonstrates why the making a subjective judgement of this kind is rational. Hobbes (2008: 79) states that:

[E]very man by right of nature is judge himself of the necessity of the means, and of the greatness of the danger. For it be against reason, that I be judge of mine own danger myself, then it is reason, that another man be judge thereof. But the same reason that maketh another man judge of those things that concern me, maketh me also judge of that that concerneth him.

Indeed, the logic of subjective self-preservation would suggest that the individual take out his potential threats before they are in a position to do the same to him. It is this element to the right of self-defence that leads to what Tuck calls "radical instability" as it means that even if all have peaceable or good intentions, violence can still rationally ensue due to each individual making his own judgement about threats to himself. Similarly, Pinker (2003: 322) notes the possibility of a person concluding that "the only option for self-protection may be to wipe out potentially hostile neighbors first in a preemptive strike." This would be a logical conclusion and not one reached through a desire to cause harm, thus Pinker notes that " $\mathrm{t}$ ]ragically, you might arrive at this conclusion even if you didn't have an aggressive bone in your body." Instead it is brought about through the logic of self-preservation. It is to be stressed here that the motivation that brings about violence is "fear" (Baliga and Sjöström, 2010:6), and a necessary lack of comprehension of the "true" state of the other (ibid:7). 
This is the concept of "The Hobbesian Trap". The Hobbesian Trap has generally been examined within the context of international relations; that is, conflict between states. Steven Pinker's definition of the Hobbesian Trap thus places its stress upon wars between countries. Pinker (2000) states that:

The "Hobbesian trap," in which a nation is tempted to attack a neighbor out of fear that it would otherwise attack first, like an armed homeowner who surprises an armed burglar, tempting each to shoot first to avoid being shot.

The "Hobbesian Trap" is thus a pre-emptive self-defensive action motivated by fear. But Pinker's definition reveals that the concept of the "Hobbesian Trap" has relevance in conflicts between two individuals, and it is in fact upon such a basis that the concept ultimately rests.

This paper has already demonstrated that, for Hobbes, man has a right, indeed an obligation, of self-preservation. It has shown that he is free to decide what to do about a threat to himself. And it has shown that he is to determine by himself what constitutes a threat. There is a further destabilizing element in connection with a rational obligation to self-defence. It is the question as to what aspect of the "self" is to be defended, and as to whether it is to be limited simply to his life.

Hobbes explicitly recognizes that human beings come into conflict for a wider range of reasons than simply self-preservation understood in its strictest terms. This is because for human beings "self" is defined more broadly that just mere existence. Self-regard is significant for an individual's sense of self. Hence, Hobbes (1985: 185) explicitly recognizes that concern for "Reputation" underlies one of the "three principall causes of quarrell" that exist "in the nature of man." Those for whom "Reputation" matters "use Violence...for trifles, as a word, a smile, a different opinion, and any other signe of undervalue" which can be "direct in their Persons" or even "their Name" (ibid). "Reputation" is equivalent to "honour" (Baliga and Sjöström, 2010:1).

If this broader sense of the "self" is given the obligation to be defended by the individual then the Hobbesian Trap sees a far greater element of Tuck's "radical instability". As it is the agent himself that is left by Hobbes to decide upon supposed threats to himself, it has to be the case - as there is for Hobbes no higher authority to determine it for him - that he may decide too what "self" is to be defended by him. In 
this case, the Hobbesian Trap can be sprung into operation not simply by a subjective determination of a potential threat to the actor's life but also to his self-esteem or honour.

The possibility that self-esteem is tied up in the Hobbesian Trap is entered into by Sandeep Baliga and Tomas Sjöström. In their paper (ibid: 1) on "The Hobbesian Trap", which examines the Hobbesian Trap through "Game Theory", these two authors examine "why a reputation is worth fighting for." Of course, closely connected with this is the question of why reputation is worth killing for. Hence, the concept of "honour violation" can be understood to be a cause for violence, and as the threat of "honour violation" is left to the judgement of the individual, it can be dealt with pre-emptively.

\section{Honour}

For the example of the broader-based Hobbesian Trap in this paper, the element of self-esteem to be looked at is that of the concept of a man's honour resting upon the chastity of his wife. Of course, this is not to say that such a concept is accepted by Hobbes as something with an intrinsic value. Indeed, as a moral-relativist he cannot hold such an outlook. Hobbes (1985: 187) himself states that " $t$ the Desires, and other Passions of man, are in themselves no Sin. No more than the Actions, that proceed from those Passions." Hence a wife's infidelity cannot be regarded as immoral and any supposed impact to a man's self-esteem from it is meaningless. Hobbes, as has been mentioned, accepts the existence of only one value and that is the right of self-preservation. The reason for this being the only value is that it is the only value natural to all human beings (Tuck, 1992:172). Honour tied to spousal chastity is not something that is valued by all human beings and as such is a relativist value.

Indeed, at certain times and places the idea of man's honour being connected to his wife's chastity would even be an alien one. An example can be found in The Travels of Marco Polo. Polo (1958: 88) relates that in the province of Kamul:

I give you my word that if a stranger comes to a house here to seek hospitality he receives a very warm welcome. The host bids his wife do everything that the guest wishes. Then he leaves the house and stays away two or three days. Meanwhile the guest stays with his wife in the house and does what he will with her, lying with her in one bed just as if she were his own wife; and they lead a gay life together. 
Polo (ibid) adds that in this way "[a]ll the men of this city and province are thus cuckolded by their wives; but they are not in the least ashamed of it." Actually, by revealing that they feel no shame, it is almost certain they see nothing wrong in what they do and thus the idea that the men are "cuckolded" is almost certainly Polo's and not their own. And, even if Polo's account is to be treated with scepticism, in modern times, wifelending among "certain isolated ethnic groups" has been documented in Indonesia, for instance (Pangkahila, 2004:536).

In other times and places, the existence of the concept of a man's honour being connected to his wife's chastity may coexist with little to no emphasis being placed upon it. For instance, in his novella The Girl with the Golden Eyes, the nineteenth-century French writer Honoré de Balzac (2012: 83) asserts that "fidelity as such was rarely, and is hardly ever likely to be, fashionable in Paris."

However, moral relativism allows for each individual or society to place value upon what it wishes. And there have been times and places in which male honour seen as being dependent upon spousal chastity has been of existential importance. For instance, in the England of the time of Hobbes, Francis Bacon (2008: 353) rates wifely qualities as being "chastity and obedience" to her husband. The idea that wives deserved death for violating their chastity was also not an alien one. Within not too distant memory was the example of Henry VIII who had put to death two of his wives for supposed adultery. In the English literature of Hobbes' time, the tragedy of the murder of Desdemona in the play Othello by William Shakespeare would surely have been regarded as justified had Desdemona actually been unfaithful to her husband. Othello's slaying of his former friend Cassio and wife Desdemona is evaluated by him as making him "[a]n honourable murderer" since "nought did I in hate, but all in honour" (Shakespeare, 2000: 293, 294). The tragic element in the play for the audience at the time is that Othello has been deliberately misled into believing his wife and friend had conducted an affair.

Moreover, in the Islamic world, in which The Thousand and One Nights was developed, there is a long tradition of male honour being dependent upon the chastity of their spouses. Indeed, it has been dependent on even more than just their literal chastity. Ebru Boyar and Kate Fleet (2010: 255 - my italics) state that in Ottoman Istanbul " $\mathrm{t}$ ] he danger of unseemly female behaviour was clearly felt keenly by their husbands, whose honour would be stained by any unsuitable actions of their wives." This outlook has remained effectively unchanged in certain 
parts of Turkey, if not necessarily in Istanbul itself, into the Republican era. The legal expert Habibe Yllmaz Kayar, explains how this outlook leads to murder in what is known as "honour killing". This occurs when "men" who "believe they have the right over" the "women" they are related to, among which are obviously numbered their "spouses", feel that their "honour and dignity" has been "denigrated". This, to them, denigration is deemed to have been brought about through their women having acted against "the dominant tradition or moral values" of their society. ${ }^{2}$

But for the broader-based Hobbesian Trap to operate, it is the individual who decides what a threat to his fundamental self is, and moral relativism allows him to regard a violation of his honour as just such a threat. It also enables him to rationally act pre-emptively to prevent such a violation. Moreover, the idea that gender-relations can get caught up in the Hobbesian Trap - albeit not necessarily with fatal consequences - is touched upon by Étan Levine. Levine (2009: 123 original italics) states that "any ideology teaching the inevitability of struggle between the sexes is a 'Hobbesian Trap' wherein persons are moved to dominate out of fear of otherwise being dominated." Such an example of the broader-based Hobbesian Trap in operation occurs in the frame story of The Thousand and One Nights. Before examining how it provides an example of the broader-based Hobbesian Trap in operation, a brief summary of the frame story is given here.

\section{The Hobbesian Trap in the Frame Story of The Thousand and One Nights}

The main focus of the frame story is on Shariyar and his younger brother Shahzaman, sons of a powerful Sassanid king. Shariyar has inherited his enormous kingdom, while Shahzaman separately rules over Samarkand (TON:15). The two brothers are close. Hence, when, after a two-decade period of ruling "happily" in their respective realms Shahzaman is invited to visit Shahriyar, he enthusiastically accepts (ibid). However, soon after setting out on his visit, Shahzaman realizes he has forgotten something in his palace, returns there without being announced, and catches his wife in flagrante delicto with a slave.

Having slain the two, he sets off again, but his visit to his brother is soured by what he has seen and he remains in his brother's palace in a state of depression. He is so dispirited that he rejects an invitation to go

2) http://www.turkhukuksitesi.com/showthread.php?t=8905 
hunting with his Shahriyar, in whose absence he unexpectedly witnesses his wife also being unfaithful with a slave (TON:17). Having been told of this, Shahriyar remains sceptical until, through means of a ruse, he has witnessed his wife's infidelity for himself (ibid). This leads Shahriyar to get his brother to agree to "roam the world" together "looking to see if any other king has ever met with such disgrace" (TON: 18).

After prolonged travel, the two kings take a rest, and witness a jinnee with a casket rise out the nearby sea. The casket contains a girl who had been abducted by the jinnee on her wedding night and who is let free while the jinnee sleeps (ibid). She forces the two reluctant kings to have sexual intercourse with her by threatening to wake the jinnee if they do not accede to her demand (ibid). It turns out that the girl takes a gold ring from each of her conquests, and with the rings now presented to her by Shahriyar and Shahzaman she has a total of a hundred. She then tells the kings that despite the jinnee keeping her locked away in the casket "he little knew how cunning we women are" (TON: 19). The two kings then return to Shahriyar's palace where Shahriyar slays his wife and her accomplices (ibid).

Full of the belief of the perfidy of women but seemingly not willing to renounce a life of the flesh, Shahriyar devises a method by which he can remain sexually satisfied without facing the risk of infidelity. It is stated that "he made it his custom to take a virgin in marriage to his bed each night, and kill her the next morning" (ibid). Indeed, he continues with this action until, three years having passed "a clamour rose among the people, some of whom fled the country with their daughters" (ibid).

This unendurable situation is resolved through the action of Shahrazad, daughter of Shahriyar's vizier. She requests that her unwilling father give her to the king in marriage in the belief that she can bring his wife killing to an end (ibid). She weds him, but following the consummation of their marriage, through a prearranged plan, her sister turns up and asks to hear a story (TON:22-3). As Shahrazad, "a highly educated" (Wiesner-Hanks, 2011: 85) and "learned and thoughtful young woman" (Clinton, 1989:43) is such a consummate story-teller, and as she leaves her tales "with cliff-hanger endings" (Wiesner-Hanks 2011:85), Shahriyar does not have her put to death as he is avid to hear more. Indeed, this story-telling period lasts for 1,001 nights - hence the title of the literary work - and it gets the king to alter his opinion of women, or at least of the potential of Shahrazad. In any case, the period 
of woman killing is over, and as such, Shahriyar comes to name her "the salvation of my people" (TON: 406).

Shahriyar falls into the borader-based Hobbesian Trap laid out above. His pre-emptive killings of his wives following on the morning after the consummation of his marriages to them can be regarded as rational as he presumes them to be a threat to his fundamental self. $\mathrm{He}$ wishes to neutralize the threat they pose to him before they are able to act on their potential.

It is the discovery of the unfaithfulness of two women in particular that convinces Shahriyar that wives in general are potential threats to a man's honour. The first is when he witnesses his wife's adultery with his own eyes (TON: 18). This has an impact of what Jermone W. Clinton describes as "destructive force" (Clinton, 1989:36). Clinton (ibid: 36-7) states that:

Shahriyar's wife has chosen not only to cuckold him, an act of tremendous hostility by itself, but also to do so with a man who is as opposite and inferior to him as Islamic society can provide, a black slave. She has made her act of infidelity a kind of rite of the harem involving forty of her male and female slaves. Moreover it is a rite that she apparently celebrates every time the king leaves the palace.

And in especial regard to the question of honour, it is to be noted that "although it is carried out in the apparent seclusion of the harem, with so many privy to the secret, it can hardly have been a secret at all, except from Shahriyar" (Clinton, 1989: 37). Thus, he is probably shamed within the capital of his kingdom as although he has only just discovered the truth, he must feel that "what has only now become known to him has long been common knowledge in the court" (ibid).

There is a further symbolic element to what Shahriyar would regard as an assault on his honour. Clinton (ibid) states that:

As Shahriyar looks down on his wife and her attendants, he is observing what was for him both the most secret and secure point in his kingdom. The garden is at the heart of the castle and protected by its walls, and the walls of the castle are protected both by his twenty years of just rule and by those of his father as well. The garden is not simply a quiet and beautiful place within the palace, it is a symbol and metaphor both for Shahriyar's psyche and self, and for the quality of his performance as ruler of his kingdom. Shahriyar's wife has invaded, violated and betrayed him in the very center of his personal and public being. 
The second unfaithfulness is that of the girl kept by the "gigantic jinnee" (TON:18). Having heard the jinnee call the girl "[c] haste and honourable lady" (ibid), Shahriyar learns that whilst the jinnee is asleep she has in fact betrayed this spirit with ninety-eight other men preceding her forcing Shahriyar himself and his brother to have sexual intercourse with her (TON:19). These two situations are interpreted by Shahriyar as, in the words of Clinton (1989: 40), "final and unarguable proof that all women are evil and bent on the betrayal of men, and that all men are, like him, vulnerable to their power."

Having executed his queen, Shahriyar enters the logic of the broader-based Hobbesian trap. Regarding all possible future spouses as potential threats to his honour and seemingly unwilling to forgo the pleasure of sexual relations, he resolves to physically satisfy himself with them and then remove them as threats before they are able to act. The text states that " $\mathrm{t}$ ] henceforth [Shahriyar] made it his custom to take a virgin in marriage to his bed each night, and kill her the next morning" (TON:19). It is certainly the case by doing so he becomes "a monster of injustice" (Clinton, 1989:36). But it is also averred that he "goes mad" (Dols, 1992:2) or "has gone mad" (Clinton, ibid) and has fallen into a "murderous and violent psychosis" (Clinton, 1989: 40). Indeed, the frame story itself, described by Michael W. Dols as "a story of madness" (Dols 1992:2), suggests that Shahriyar is in a psychotic state as his exit from it is described as a "salvation" (TON:405).

This may be the case, but in the light of the broader-based Hobbesian trap, Shahriyar's action, however repellent it may be, is not irrational but rather based on reason, and as such even more unsettling. Clinton acknowledges that Shahriyar's action is a "draconian policy by which he hopes to prevent another such shattering and humiliating betrayal" (Clinton 38). If, for Shahriyar, his self-esteem is central to his fundamental self, and as such threats to his honour are effectively existential ones, then by falling into the Hobbesian trap he has in fact found a rational solution to his problem. Having seen women deceive their spouses, he is aware that he cannot know what their secret thoughts and intentions are. Thus, he is left to evaluate them as potential threats to his honour. And, it is rational for him to eliminate those potential threats before their threat can be actuated.

In order to demonstrate that the broader-based Hobbesian Trap is at work in the frame story of The Thousand and One Nights it is necessary 
to prove that it is a self-regard as to honour that motivates Shahriyar. If he is simply suffering from a feeling of emotional betrayal by his original queen then his actions in wife killing cannot be explained by the broader-based Hobbesian Trap. They would then be some kind of irrational vicarious revenge upon women in general. For the Hobbesian Trap to be sprung, Shahriyar needs to feels effectively existentially threatened. The text however, gives sufficient evidence to suggest that Shahriyar, and indeed his brother Shahzaman as well, are affected by the infidelities of their wives through considerations of honour and not emotional betrayal.

Nevertheless, that the infidelities of their wives affect both men in a profoundly emotional manner is not in doubt. For Shahzaman, it is stated that "the world darkened before his eyes" on beholding his wife in the embraces of the slave (TON: 15). Also, his eagerly anticipated visit to his brother is entirely overshadowed by it, as he remains "pale and sick at heart" (TON: 16) and describes his condition as "a painful sore" and "melancholy" (TON: 16, 17). As for Shahriyar, the sight of his wife taking part in her orgy left him "[h]alf demented", and inspires him to temporarily give up the affairs of his kingdom (TON: 18).

Yet, there are no textual considerations that support a supposition that this emotional distress is brought about through feelings of emotional betrayal. They exist however the supposition that it is brought about through considerations of honour. Most explicitly and as has been already mentioned, Shahriyar, in the immediate aftermath of having seen the behaviour of his wife, describes it as a "disgrace" in relation to himself and not to her (ibid). Moreover, having lost his violent rigidity after having heard Shahrazad's tales for a thousand and one nights, he is now able to praise a woman, and that is his wife Shahrazad. He praises her both within the privacy of their own quarters and in public. In the first case, he glowingly describes her as "chaste and tender, wise and eloquent" (TON: 405) and in the second case shortens it to "chaste, wise and eloquent" (TON: 406). Her wisdom and eloquence are indeed manifest in the work, as she has been able to entertain and enlighten the king consecutively night after night with tales that have been described by a modern critic as "masterpieces in the art of story-telling" (Dawood, 1973:7) for a period of almost three years. That Shahriyar chooses to praise her qualities of wisdom and eloquence after praising her chastity shows the central concern that this plays in relation to women within 
his psyche. And an obsession with chastity strongly implies an obsession with honour, as the two terms are almost synonymous. Indeed, the jinnee that emerges from the sea with the casket ignorantly addresses his captive girl as "[c]haste and honourable lady" (TON: 18 - my italics).

Particularly strong evidence for considerations of honour rather than emotional betrayal being of sole importance to the kings is revealed by their altered emotional state after having witnessed a greater victim of infidelity. Whilst it is probable that a victim of infidelity may take some solace from finding that he is not alone in his condition, it is extremely improbable that it would cure him of his state of depression and even make him happy. Yet this is precisely what happens in the cases of both kings. Having witnessed the orgy of Shahriyar's wife, Shahzaman - the lesser of the two kings - exclaims that "By Allah, my misfortune is lighter than this" and is not only "dejected no longer" but in his "altered condition" is actually "restored to good spirits and full health" (TON: 17). As Clinton puts it "Shahzaman's deep depression was cured because he saw that his older, more powerful brother had suffered an even worse humiliation than he had" (Clinton, 1989: 40). Similarly, Shahriyar on having seen and learned how the "mighty jinnee" has been repeatedly deceived by the girl in the chest, he, along with Shahzaman regard their "own misfortune as light indeed" (TON: 19), and it immediately brings to an end their melancholic pilgrimage. ${ }^{3}$ Before ending with this section it is also to be noted that both wives are punished with death by the kings (TON: 16, 19), the only punishment that is regarded as acceptable in cases of honour violations as will be examined below.

There is another factor present in the frame story that supports the contention that Shahriyar enters the broader-based rational Hobbesian trap. It is that outside of questions relating to his honour he cannot be regarded as in any way a psychotic ruler. On the contrary, not only prior to his discovery of his wife's infidelity is he described as having "governed" his kingdom "with such justice that all his subjects loved him" (TON: 15), but following his redemption through Shahrazad he is also described as having "reigned over his subjects in all justice" until his death (TON: 407). It is also noted by Clinton that even during his

3) It is to be noted here that Clinton $(1989,40)$ sees Shahriyar's supposed return to equilibrium as "really a deeper madness masquerading as a cure" and that he is in fact "made worse" by his encounter with the jinnee and the girl. However, this paper takes Shahriyar at his own word as it fits the pattern of emotional restoration already set by his brother Shahzaman. 
period of wife murder he is "not completely lacking in compassion" as he does not prevent Shahrazad from calling in her sister to bid farewell to her $^{4}$ (Clinton, 1989: 44). He is thus a king that is generally in a stable frame of mind, and in line with this, his three-year period of killing of his newly-wedded wives reveals a chilling logic rather than psychopathy.

\section{Conclusion}

In conclusion, this paper has demonstrated how the concept of the Hobbesian Trap is developed from the philosophical outlook of Thomas Hobbes in which self-preservation is the only right, and one that a person is obliged to engage in. It has shown that the Hobbesian Trap is sprung through a necessarily subjective rational response to perceived threats which as such can objectively not be threats at all - and that the concept itself can be widened to encompass threats to a person's essential selfregard as well as his life. It has shown that the idea of honour dependent on spousal chastity can constitute one such type of self-regard, though it is not a universal value. This paper has shown that such a broadbased Hobbesian Trap is evident in the actions of Shahriyar in killing his wives on the morning after consummating his marriages to them. It has shown that as such Shahriyar's action, however abhorent, is as such rational, and moreover that it should not be regarded as stemming from a feeling of emotional betrayal by his first queen.

It is the case of course that The Hobbesian Trap is not limited in its manifestations to literature. Even limiting the concept to self-defence as defence of life, it underpins a central plot development in a recent blockbuster film. ${ }^{5}$ Yet, its functioning in the real world is what makes it so disturbing. Hobbesian Traps can be regarded as responsible for the unnecessary loss of human life, from the killing of individuals wrongly considered to be threats - such as the shooting by police in the UK in 2005 of Jean Charles de Menezes erroneously thought by them to be a suicide bomber in a case of "mistaken identity" (Siddique, 2016) - to the

4) Clinton $(1989,44)$ also notes that were he to lack this compassion Shahrazad "would have no hope of initiating her plan."

5) In Batman $v$ Superman: Dawn of Justice, the decision taken by the character Bruce Wayne to attempt to kill the character of Superman uses the rationality of the Hobbesian Trap. Recognizing that Superman has "the power to wipe out the entire human race", Bruce Wayne concludes that "if we even believe there is even a 1 percent chance he is our enemy, we have to take it as an absolute certainty and we have to destroy him" (qtd. in Rothman, 2016). 
eruption of conflicts costing millions of lives such as the First World War. It could even have led to the ending of civilization as we know it on this planet had the Cuban Missile Crisis reached its potential conclusion. ${ }^{6}$ Yet, this example also reveals how the Hobbesian Trap can be defused. And, it is the case, as Baliga and Sjöström (2010: 8) have demonstrated, that the Hobbesian Trap once entered into can indeed be "mitigated" and "almost completely escaped" (ibid: 10), and as such it does not have to inevitably lead to violence. It is the inability to know the intention of the potential threat that causes a pre-emptive strike. And it is impossible to fully know a potential opponent's intentions. However, "confidencebuilding measures" (Pinker, 2003: 335), such as "communication" (B\&S. 8), help to reduce the aura of threat around a potential opponent. Thus, symbolically, the Hobbesian Trap of the Cuban Missile Crisis, in which " $[t]$ he importance of open communication between superpower leaders became evident (Schier, 2008: 87) - ended with the establishment of a direct telephone link - or "hotline" - between the White House and the $\mathrm{Kremlin}^{7}$ (ibid). The example of the Hobbesian Trap in the frame story of The Thousand and One Nights is resolved in a similar way. Whilst Shahrazad engages in her style of suspenseful storytelling to keep herself alive (Wiesner-Hanks, 2011:85), she is also encouraging the king through her tales to recognize what Clinton (1989: 44) calls "the variety and complexity of human personality, both male, and in particular, female." As the nights of tales progress, Shahriyar's confidence in her rises and she enters what Pinker ${ }^{8}$ calls the "moral circle" (Pinker, 2003: 335) of the king, whilst she is also implicitly undermining his "war on women" with the subjects of her stories ${ }^{9}$ (Clinton, 1989: 46). As Shahrazad is humanized for Shahriyar, he consequently no longer regards Shahrazad as a threat to his honour, and in addition "his negative opinion of women" (Wiesner-Hanks, 2011: 85) appears even to be changed. Thus, Shahriyar's "salvation" (TON: 405) in the story can be regarded as his being adroitly led by Shahrazad out of the broad-based Hobbesian trap - in accordance

6) Pinker (2003: 334) notes that during the Cuban Missile Crisis, the leaders of both the US and the USSR "understood they were in a Hobbesian Trap."

7) This "hotline" was also designed to be used in such a way as to limit the possibility of inflaming tensions during communications. Helga Schier states that " $[t]$ he hotline relies on the written word rather than voice or video transmission. This allows for time to think before responding and to avoid the potential misinterpretation in tone of voice and body language" (Schier, 2008: 87).

8) After Peter Singer. See: Pinker, 2003: 166-8.

9) See: Clinton, 1989: 45-8. 
with her earlier stated aim of becoming "the cause of" the "deliverance" of "the daughters of Moslems" (TON: 19) - back to being the king famed for justice that he once was.

\section{References}

Bacon, F. (2008). Brian Vickers (Ed.), The Major Works. Oxford: Oxford University Press.

Baliga, S., \& Sjöström, T. (2010). “The Hobbesian Trap”. Retrieved from: http:// www.kellogg.northwestern.edu/faculty/baliga/htm/hobbesiantrap.pdf

Balzac, H. (2012). The Girl with the Golden Eyes and Other Stories. Peter Collier (Trans.). Oxford: Oxford University Press.

Boyar, E., \& Fleet, K. (2010). A Social History of Ottoman Istanbul. Cambridge: Cambridge University Press.

Clinton, J. W. (1989). "Madness and Cure in the Thousand and One Nights". Ruth B. Bottigheimer (Ed.), Fairy Tales and Society: Illusion, Allusion, and Paradigm (pp. 35-52). Philadelphia: University of Pennsylvania Press.

Dawood, N. J. (Translated with an Introduction, 1973). Tales from the Thousand and One Nights. Middlesex: Penguin Books Ltd.

Dols, M. W. (1992). Majnūn: The Madman in Medieval Islamic Society. Dianna E. Immisch (Ed.), Oxford: Clarendon Press.

Hampsher-Monk, I. (1992). A History of Modern Political Thought: Major Political Thinkers from Hobbes to Marx. Oxford: Blackwell Publishers.

Hobbes, T. (2008). Human Nature and De Corpore Politico. J. C. A. Gaskin (Ed.). Oxford: Oxford University Press Inc.

Hobbes, T. (1985). Leviathan. C. B. Macpherson (Ed.). Middlesex: Penguin Books Ltd.

Levine, É. (2009). Marital Relations in Ancient Judaism. Weisbaden: Harrassowitz Verlag.

Pangkahila, W. I. (2004). "Indonesia (Republik Indonesia) Part 1: National and Urban Perspectives."Robert T. Francoeur \& Raymond J. Noonan (Eds.), The Continuum Complete Encyclopedia of Sexuality (pp. 533-43). New York: The Continuum International Publishing Group Inc.

Pinker, S. (2000). “All about Evil”. New York Times Book Review. Retrieved from: https:/www.nytimes.com/books/00/10/29/reviews/001029.29pinkert.html

Pinker, S. (2003). The Blank Slate: The Modern Denial of Human Nature. London: Penguin Books Ltd. 
Polo, M. (1958). The Travels of Marco Polo. Ronald Latham (Trans.). Middlesex: Penguin Books Ltd.

Rothman, M. (2016). “Batman v Superman': New Clip Explains Why the Two Superheroes Are Fighting." Retrieved from: http://abcnews.go.com/ Entertainment/batman-superman-clip-explains-superheroes-fighting/ story?id=36500581

Schier, H. (2008). The Cuban Missile Crisis. Minnesota: ABDO Publishing Company.

Shakespeare, W. (2000). Othello. Cedric Watts (Ed.). Hertfordshire: Wordsworth Editions Limited.

Siddique, H. (2016). "Who was Jean Charles de Menezes?" The Guardian Article. Retrieved from: http://www.theguardian.com/uk-news/2016/ mar/30/jean-charles-de-menezes-your-questions-answered

Tuck, R. (1992). Hobbes. Keith Thomas (Ed), Great Political Thinkers. Oxford: Oxford University Press. 107-238.

Wiesner-Hanks, M. E. (2011). Gender in History: Global Perspectives. Chichester: Blackwell Publishing.

Zimring, F. A. (1998). “The Sneaky Thrill of Breaking the Law.” New York Times Book Review. Retrieved from: http://www.nytimes.com/1988/11/20/ books/the-sneaky-thrill-of-breaking-the-law.html?pagewanted=all 